\title{
Characterization of Cylindrocarpon Species, the Cause of Black Foot Disease of Grapevine in California
}

\author{
Elsa Petit and Walter Douglas Gubler, Department of Plant Pathology, University of California, Davis 95616
}

\begin{abstract}
Petit, E., and Gubler, W. D. 2005. Characterization of Cylindrocarpon species, the cause of black foot disease of grapevine in California. Plant Dis. 89:1051-1059.

This study investigated phylogenetic divergence, morphological difference, and pathogenic variation among Cylindrocarpon species isolates associated with black foot disease of grapevine (Vitis sp.) in California. To assess phylogenetic divergence, we sequenced the internal transcribed spacer (ITS) of the nuclear ribosomal DNA (rDNA), partial beta-tubulin (BT) gene introns and exons, and the small subunit mitochondrial rDNA. Isolates associated with black foot disease belonged to two paraphyletic species, Cylindrocarpon destructans and C. macrodidymum. The morphology of these isolates was in agreement with published descriptions of both species. We found that $C$. macrodidymum isolates were reliably distinguishable from $C$. destructans isolates in culture by a unique orange-dark brown colony color on $2 \%$ malt extract agar and genetically by a species-specific 52-bp DNA insertion in the BT region. Selected isolates of each species inoculated onto grapevine rootstock $5 \mathrm{C}$ caused typical black foot disease symptoms. This is the first report of $C$. macrodidymum in California.
\end{abstract}

Additional keywords: mtSSU rDNA, Nectriaceae, Neonectria, phylogeny, vineyard

Black foot disease is a recently identified but worsening problem in California vineyards (22). Roots of symptomatic grapevines (Vitis sp.) show black, sunken, necrotic lesions (23). In cross section, the base of the trunk appears necrotic and xylem vessels are plugged with black inclusions and tyloses (23). Aboveground, leaves of infected vines appear to be scorched by water stress, and the entire vine becomes stunted and frequently dies (23). Young vines up to 8 years old are primarily affected by the disease $(6,17)$. Because diseased plants must be removed, the disease causes substantial economic losses due to replanting costs. First reported in France in 1961 (17), the disease occurs in all the major viticulture regions throughout the world, including Italy (9,10), Portugal (20), Spain (1), South Africa (11), New Zealand (11), and Australia (26).

Campylocarpon fasciculare Schroers, Halleen \& Crous, Campylocarpon pseudofasciculare Halleen, Schroers \& Crous, Cylindrocarpon destructans (Zinssmeister) Sholten, Cylindrocarpon macrodidymum Halleen, Schroers \& Crous, and Cylindro-

Corresponding author: W. D. Gubler

E-mail:wdgubler@ucdavis.edu

GenBank Accession Numbers for nucleotide sequences are AY997532 to AY997620.

Accepted for publication 25 May 2005.

DOI: 10.1094/PD-89-1051

(C) 2005 The American Phytopathological Society carpon obtusisporum (Cooke \& Harness) Wolleweb. have all been described as the fungal causal agents of black foot disease in grape-growing regions outside of California. Campylocarpon fasciculare and Campylocarpon pseudofasciculare were recently shown to cause black foot disease in South Africa (11). Since Cylindrocarpon destructans was first reported in 1961 in France (17), it has been isolated from diseased vines in Sicily (9), Portugal (20), Australia (26), New Zealand (11), and South Africa (11). C. macrodidymum has been recently reported in Australia, New Zealand, and South Africa (11). C. obtusisporum was detected in Sicily in 1975 (10). In California, only $C$. destructans and C. obtusisporum have been reported to cause black foot disease (23). Given the association of several different fungi on grapevines with the disease outside of California, it is important to identify the Cylindrocarpon species that cause the disease in California.

The genus Cylindrocarpon (teleomorph: Neonectria) contains approximately 125 described species (18). Both the anamorph and teleomorph can be used to classify Cylindrocarpon species. The teleomorph of $C$. destructans was observed in France on grapevines (17), and in vitro sexual crosses for $C$. macrodidymum isolates from South Africa and Australia have been successful (11). Nevertheless, the sexual stage of Cylindrocarpon spp. has never been observed in California vineyards or in the laboratory. Therefore, only the anamorphic characteristics have been used to identify Cylindrocarpon species in Cali- fornia (22). These characteristics are traditionally morphological and include colony pigmentation, growth rate, production of chlamydospores, and microconidial/macroconidial shape and size (2). Past research showed that Cylindrocarpon isolates associated with black foot disease in California showed great variation in morphology, and it is unclear whether this variation reflects intra- or inter-species differences (E. Petit and W. D. Gubler, ECCB 2003).

Although morphology is used extensively in fungal identification, it is often insufficient to differentiate species when used alone (27). Recently, gene sequence information has been used to supplement morphological descriptions (27). Often, fungi that were previously identified as a single species when classified on the basis of morphology were found to correspond to several distinct species when described by multigene genealogy (27). This has been the case for $C$. destructans isolates on ginseng (25). Distinct species may vary in important phenotypic characters, including longevity in the field, host range, aggressiveness, and susceptibility to different disease control treatments. Therefore, a complete knowledge of species involved in a disease could help researchers improve disease control. The objective of this study was to identify, by means of multigene phylogeny, morphological characteristics, and pathogenicity, the species causing black foot disease of grapevine in California.

\section{MATERIALS AND METHODS}

Isolates. We collected a total of $31 \mathrm{Cyl}$ indrocarpon isolates from 19 vineyards in six counties throughout California between 1998 and 2003 (Table 1). Isolates were recovered from roots and root crown of grapevines exhibiting symptoms typical of black foot. The margin of the symptomatic region was surface-sterilized in $10 \%$ bleach for $1 \mathrm{~min}$. Tissue pieces, about 2 $\mathrm{mm}$ in diameter, were placed on potato dextrose agar (PDA) (DIFCO, BD Micro Biology Systems, Franklin Lakes, NJ) amended with tetracycline hydrochloride $(0.01 \%)$ (SIGMA-ALDRICH, St Louis, $\mathrm{MO})$ and incubated at room temperature for 4 days. Isolates were identified as $\mathrm{Cyl}$ indrocarpon spp. based on colony morphology and conidial characteristics. Single spore cultures were initiated using a previously described method (12). A conidial suspension was prepared by transferring a loopful of conidial mass into $1 \mathrm{ml}$ 
of sterile distilled water, and the concentration of the suspension was adjusted to approximately 10 spores per microliter. A $0.1-\mu \mathrm{l}$ drop of the spore suspension was placed on PDA. After incubation at $25^{\circ} \mathrm{C}$ for 12 to $24 \mathrm{~h}$, each plate was inspected under a microscope at $\times 100$ magnification. Single germinating spores were transferred to new PDA plate. For long-term storage, cultures were transferred to Whatman no. 1 filter papers (Whatman International Ltd., Maidstone, England) overlaid on PDA, and after colonization, the filters were dried and stored at $-20^{\circ} \mathrm{C}$. For phenotypic and genetic comparison, we added to our Californian collection Cylindrocarpon isolates from grapevines obtained from other collections (Table 1). These additional isolates were from Chile (CH103), France (FR102), and South Africa (C. destructans [CBS112602] and $C$. macrodidymum [CBS112605]) (Table 1).

DNA extraction, polymerase chain reaction (PCR), sequencing, and multigene phylogenies. Fungal mycelium and spores were collected from PDA plates after 2 weeks of growth at $25^{\circ} \mathrm{C}$ in a 12 -h light/dark cycle, illuminated by fluorescent strip lights and near-ultraviolet light (366 $\mathrm{nm})$. Genomic DNA was extracted using QIAGEN DNeasy plant minikit (QIAGEN
Inc., Valencia, CA) following the manufacturer's protocol. DNA concentrations were quantified with commercial standards on agarose gels stained with ethidium bromide. Purified DNA was stored at $-20^{\circ} \mathrm{C}$.

We analyzed three regions of the genome: the internal transcribed spacer of ribosomal DNA (ITS rDNA), partial sequences of the beta tubulin (BT) gene, and the mitochondrial small subunit ribosomal DNA (mtSSU rDNA). Templates of the ITS region (comprising ITS1, 5.8S ribosomal RNA gene, and ITS2) were amplified using primers ITS1 and ITS4 (29). Partial sequences of the BT gene, BT1 and BT2, were amplified using primers BT1a/BT1b and BT2a/BT2b, respectively (8). Partial sequences of the mtSSU rDNA were amplified using primers NMS1 and NMS2 (15). ITS rDNA and BT1 regions were amplified and sequenced for all isolates $(n=35)$. Based on the phylogeny from these regions, as described below, we amplified the other regions for only 10 selected isolates. PCR reactions contained $200 \mu \mathrm{M}$ of dNTP (Applied Biosystems, Warrington, UK), $0.375 \mu \mathrm{M}$ of each primer, 0.5 units of Taq DNA polymerase (QIAGEN), 1× PCR buffer supplied together with the Taq, and $10 \mathrm{ng}$ of template DNA adjusted with purified water (Milli-Q

Table 1. Cylindrocarpon isolates from grapevines used in this study

\begin{tabular}{|c|c|c|c|c|}
\hline Species $^{\mathrm{y}}$ & Isolate & Geographic origin & Source ${ }^{\mathrm{z}}$ & Year $^{\mathbf{z}}$ \\
\hline \multirow[t]{17}{*}{ C. destructans } & CBS112602 & Worcester, South Africa & F. Halleen & 1999 \\
\hline & FR102 & Champagne, France & P. Larignon & $\mathrm{n} / \mathrm{a}$ \\
\hline & USME116 & Philo, Mendocino Co., CA & E. Petit & 2003 \\
\hline & USNA93 & Napa, Napa Co., CA & H. Scheck & 1999 \\
\hline & USNA98 & St. Helena, Napa Co., CA & H. Scheck & 1999 \\
\hline & USSC 20 & Santa Clara, Santa Clara Co., CA & H. Scheck & 1998 \\
\hline & USSO54 & Sonoma, Sonoma Co., CA & E. Petit & 2003 \\
\hline & USSO77 & Sonoma, Sonoma Co., CA & H. Scheck & 1999 \\
\hline & USSO2 & Hopland, Sonoma Co., CA & H. Scheck & 2002 \\
\hline & USSO131 & Geyserville, Sonoma Co., CA & E. Petit & 2003 \\
\hline & USSO143 & Geyserville, Sonoma Co., CA & E. Petit & 2003 \\
\hline & USSO126 & Sonoma, Sonoma Co., CA & E. Petit & 2003 \\
\hline & USSO150 & Sonoma, Sonoma Co., CA & E. Petit & 2004 \\
\hline & USSO78 & Sebastopol, Sonoma Co., CA & H. Scheck & 1998 \\
\hline & USST114 & Ceres, Stanislaus Co., CA & E. Petit & 2003 \\
\hline & USST148 & Ceres, Stanislaus Co., CA & E. Petit & 2003 \\
\hline & USST113 & Hugson, Stanislaus Co., CA & E. Petit & 2003 \\
\hline \multirow[t]{18}{*}{ C. macrodidymum } & CBS112605 & Wellington, South Africa & F. Halleen & 2000 \\
\hline & CH103 & Chile & $\mathrm{n} / \mathrm{a}$ & $\mathrm{n} / \mathrm{a}$ \\
\hline & US40 & $\mathrm{CA}$ & H. Scheck & $\mathrm{n} / \mathrm{a}$ \\
\hline & US138 & $\mathrm{CA}$ & E. Petit & 2003 \\
\hline & USME115 & Philo, Mendocino Co., CA & E. Petit & 2003 \\
\hline & USME149 & Philo, Mendocino Co., CA & E. Petit & 2003 \\
\hline & USNA136 & St. Helena, Napa Co., CA & E. Petit & 2003 \\
\hline & USSL152 & Woodland, Solano Co., CA & E. Petit & 2003 \\
\hline & USSO130 & Sonoma, Sonoma Co., CA & E. Petit & 2003 \\
\hline & USSO74 & Windsor, Sonoma Co., CA & H. Scheck & 1999 \\
\hline & USSO133 & Geyserville, Sonoma Co., CA & E. Petit & 2003 \\
\hline & USSO140 & Geyserville, Sonoma Co., CA & E. Petit & 2003 \\
\hline & USSO119 & Sonoma, Sonoma Co., CA & E. Petit & 2003 \\
\hline & USSO124 & Sonoma, Sonoma Co., CA & E. Petit & 2003 \\
\hline & USSO107 & Healdsburg, Sonoma Co., CA & E. Petit & 2003 \\
\hline & USSO151 & Sonoma, Sonoma Co., CA & E. Petit & 2003 \\
\hline & USSO117 & Sonoma, Sonoma Co., CA & E. Petit & 2003 \\
\hline & USSO146 & Sonoma Co., CA & E. Petit & 2003 \\
\hline
\end{tabular}

${ }^{\text {y }}$ Species was determined from combined internal transcribed spacer, beta-tubulin, and mitochondrial small subunit ribosomal RNA sequence data.

${ }^{\mathrm{z}} \mathrm{n} / \mathrm{a}$ indicates not available.
Water System, Millipore, Billerica, MA) to a final volume of $20 \mu \mathrm{l}$. Amplifications were carried out in a thermalcycler (PTC200, MJ Research, Watertown, MA) as follows: $94^{\circ} \mathrm{C}$ for $4 \mathrm{~min}$ followed by 35 cycles at $94^{\circ} \mathrm{C}$ for $60 \mathrm{~s}, 58^{\circ} \mathrm{C}\left(62^{\circ} \mathrm{C}\right.$ for the mtSSU DNA) for $60 \mathrm{~s}, 72^{\circ} \mathrm{C}$ for $90 \mathrm{~s}$, and a final extension at $72^{\circ} \mathrm{C}$ for $5 \mathrm{~min}$. PCR products were purified using the QIAquick PCR Purification Kit (QIAGEN). Each region was sequenced in both directions by the University of California, Davis, Division of Biological Sciences, DNA sequencing facility using a capillary electrophoresis genetic analyzer (ABI 3730, Applied Biosystems, Foster City, CA).

Extended contiguous sequences, obtained by joining overlapping sequences, were edited using the software program Sequencher Version 4.1 (Gene Codes, Ann Arbor, MI). Sequences were aligned using the software program Clustal $\mathrm{X}$ Version 1.8 (28). Whenever possible, sequences were aligned with published GenBank sequences for comparison (Table 2). The alignment was corrected by visual inspection, and any ambiguously aligned characters were deleted in the software program MacClade Version 4.03 (16). Separate analyses were run for the combined BT1 and ITS datasets, for the combined BT2 and ITS datasets, for the ITS dataset alone, and for the mtSSU dataset alone. Nectria cinnabarina was used as an outgroup for the ITS and the mtSSU dataset analysis. In order to determine whether the BT and ITS sequence data could be combined, the partition homogeneity test, as implemented in the software program PAUP Version 4.0b10 (Sinauer Associates, Inc., Publishers, Sunderland, MA), was run with 1,000 replicates. Maximum parsimony analyses were performed in the software program PAUP Version $4.0 \mathrm{~b} 10$ using the heuristic search option, 1,000 random addition sequence replicates, and the tree-bisectionreconnection algorithm. Bootstrap values (5) were calculated using a heuristic search and 1,000 bootstrap pseudoreplications. A Bayesian analysis was also performed under the likelihood model $\mathrm{GTR}+\mathrm{I}+\mathrm{G}$ determined by Modeltest (19) using the software program Mr. Bayes Version 2.01 (14). The maximum likelihood model employed six substitution types with base frequencies estimated from the data. Rate variation across sites was modeled using a gamma distribution. The Markov Chain Monte Carlo search was run with four chains for 150,000 generations, with trees sampled every 1,500 generations (the first 20 trees were discarded). Branch lengths of sampled trees were saved. The posterior probabilities of trees and tree parameters were estimated from this distribution.

Morphology. All Cylindrocarpon isolates $(n=35)$ were cultured on Spezieller Nahrstoffarmer agar plus yeast extract (SNAY) (3), incubated at $25^{\circ} \mathrm{C}$ in a $12-\mathrm{h}$ light/dark cycle, illuminated by fluorescent 
strip lights and near-ultraviolet light (366 $\mathrm{nm}$ ), and examined after 6 days. Length and width of each type of conidium (e.g., microconidium and macroconidia that were one-septate, two-septate, and three-septate) were measured at $\times 400$ magnification with the aid of a compound microscope. Means and standard deviations were calculated from 30 observations per isolate. Data were analyzed using the GLM procedure in SAS (SAS System, Version 8.1, SAS Institute, Cary, NC). An analysis of variance (ANOVA) was used to determine the effects of species on conidial dimensions.

To determine the effect of temperature on colony growth, a mycelial disk (4-mmdiameter) from the growing margin of a 7day-old colony was placed in the center of each potato sucrose agar (PSA) plate (3). Inoculated plates were incubated at temperatures of $5,10,15,20,25$, and $30^{\circ} \mathrm{C}$ in the light conditions described above. There were three replicates for each isolate. Colony diameter was measured after 1,3 , and 6 days of incubation, and data were converted to radial growth in centimeters per day. The experiment was repeated twice. Data were analyzed using the GLM procedure in SAS. An ANOVA was used to determine the effects of species on radial growth at $25^{\circ} \mathrm{C}$ after 6 days.
The colony color on the reverse of the plate of isolates grown at $25^{\circ} \mathrm{C}$ for 6 days in the light conditions described above was observed on both PSA and 2\% malt extract agar (MEA) (Difco).

Pathogenicity. The pathogenicity of selected isolates (USME116, USST148, USSO150, US40, USNA136, and USSOL152), representative of species previously determined by the multigene phylogeny, was tested. Conidia of Cylindrocarpon isolates grown on corn meal agar (DIFCO) for 2 weeks were harvested into sterile water and adjusted to $10^{6} \mathrm{co}-$ nidia per $\mathrm{ml}$. Six-month-old rootings of grapevine rootstock cv. 5C ( $V$. berlandieri $\times$ V. riparia) grown in pro-mix $\mathrm{BX}$ (Premier Horticulture-Oceanside, CA) in 8$\mathrm{cm}$-diameter pots were drench inoculated individually with $25 \mathrm{ml}$ of spore suspension or sterile water as a control. The plants were incubated for 4 months in the greenhouse and watered three times a week with Hoagland's solution (13). Leaf symptoms of individual plants were rated on the following scale: $0=$ no symptomatic area on leaves, $1=0$ to $10 \%$ of leaf area necrotic, $2=10$ to $25 \%$ of leaf area necrotic, $3=25$ to $50 \%$ of leaf area necrotic, $4=50 \%$ of leaf area necrotic, and 5 $=100 \%$ of leaf area necrotic. Root symp- toms, determined using the gridline intersection method (7), were expressed as the percentage of root length having lesions. Symptomatic roots were aseptically plated on PDA amended with tetracycline hydrochloride $(0.01 \%)$ to reisolate the fungus, as described above. Each isolate treatment was replicated four times in a random complete block design with one plant per pot. The experiment was repeated twice. Greenhouse temperatures ranged between 20 and $25^{\circ} \mathrm{C}$. Data were analyzed using the GLM procedure in SAS. The leaf symptoms and root symptoms data were subjected to Shapiro-Wilk test for normality and Levene test for homogeneity of variance. Because the data fulfilled the criteria for normality and homogeneity, Tukey's test was used for treatment means comparisons.

\section{RESULTS}

Multigene phylogenies. ITS and BT1 sequences from 35 isolates of Cylindrocarpon species from grapevines were combined after there was no significant difference found, based on results of the partition homogeneity test $(P=0.31)$. Of the 890 nucleotides analyzed, 48 were phylogenetically informative. Maximum parsimony analyses yielded three equally

Table 2. GenBank sequences of Neonectria/Cylindrocarpon species used in the phylogenies

\begin{tabular}{|c|c|c|c|c|c|}
\hline \multirow[b]{2}{*}{ Species } & \multirow[b]{2}{*}{ Isolate } & \multirow[b]{2}{*}{ Host $^{w}$} & \multicolumn{3}{|c|}{ GenBank accession no. } \\
\hline & & & ITS $^{x}$ & BT2 $^{y}$ & $\mathrm{mtSSU}^{\mathrm{z}}$ \\
\hline N. lucida & CTR 72-71 & $\mathrm{n} / \mathrm{a}$ & & & AY380925 \\
\hline N. discophora & GJS 91-116 & $\mathrm{n} / \mathrm{a}$ & & & AF315207 \\
\hline N. viridispora & AR 2690 & $\mathrm{n} / \mathrm{a}$ & & & AY380923 \\
\hline N. phaeodisca & CTR 71-60 & $\mathrm{n} / \mathrm{a}$ & & & AY380920 \\
\hline N. fuckeliana & GJS 92-42 & $\mathrm{n} / \mathrm{a}$ & & & AY380919 \\
\hline N. veuillotiana & GJS 91-116 & Quercus sp. & & & AF315197 \\
\hline N. rugulosa & GJS 86-222 & $\mathrm{n} / \mathrm{a}$ & & & AF315208 \\
\hline$N$. coronata & CTR 71-19 & $\mathrm{n} / \mathrm{a}$ & & & AF315198 \\
\hline$N$. westlandica & GJS 85-45 & $\mathrm{n} / \mathrm{a}$ & & & AY380922 \\
\hline N. trachosa & GJS 92-95 & $\mathrm{n} / \mathrm{a}$ & & & AY380921 \\
\hline \multirow[t]{9}{*}{ C. destructans } & 1557 & Panax quinquefolius & AY295329 & AY297195 & \\
\hline & IMI 375719 & Malus sp. & AJ007356 & & \\
\hline & CTR 71-322 & $\mathrm{n} / \mathrm{a}$ & AF220969 & & \\
\hline & JAT 1378 & Cornus floridae & AY295328 & & \\
\hline & IMI 376408 & Arbutus menziesii & AJ007352 & & \\
\hline & IMI 376403 & Alnus glutinosa & AJ007351 & & \\
\hline & JAT 1551 & Prunus persica & & & AF315202 \\
\hline & FMd2.1 & Alnus rubra & & & AF315204 \\
\hline & RTDF 14 & Pseudotsuga mensiezii & & & AF315203 \\
\hline \multirow{2}{*}{ C. destructans var. coprosmae } & CTR 73-152 & Cosmospora sp. & AF220970 & & \\
\hline & GJS 85-162 & Metrosideros sp. & AY295326 & & \\
\hline \multirow[t]{4}{*}{ C. cylindroides } & CR 6 & Pseudotsuga mensiezii & AY295301 & AY297172 & \\
\hline & Cacun2ab2 & Pseudotsuga mensiezii & & & AF315201 \\
\hline & $\mathrm{P} 3 \mathrm{p} 3 \mathrm{n} 12 \mathrm{cb}$ & Pseudotsuga mensiezii & & & AF315200 \\
\hline & $\mathrm{P} 4 \mathrm{c} 2 \mathrm{n} 22 \mathrm{ad}$ & Pseudotsuga mensiezii & & & AF315199 \\
\hline C. magnusianum & CBS 730.87 & Hypocrea pachybasioides & AJ279446 & & \\
\hline C. didymum & CCFC 185212 & Pyrus sp. & AY295303 & AY297216 & \\
\hline C. obtusisporum & CBS 183.36 & Solanum tuberosum & AY677292 & & \\
\hline \multirow[t]{3}{*}{ C. heteronenum } & CBS 100318 & Malus domestica & AJ 228662 & & \\
\hline & JR0609B-2 & Malus pumila & & & AF315205 \\
\hline & GBA1 & Malus pumila & & & AF315206 \\
\hline \multirow[t]{2}{*}{ Nectria cinnabarina } & CBS 279.48 & Acer pseudoplatinus & AF163025 & & \\
\hline & GJS 91-111 & Acer sp. & & & AF315209 \\
\hline
\end{tabular}

\footnotetext{
${ }^{\mathrm{w}} \mathrm{n} / \mathrm{a}$ indicates not available.

${ }^{x}$ ITS: Internal transcribed spacer.

y BT2: Beta-tubulin 2.

${ }^{\mathrm{z}}$ mtSSU: mitochondrial small subunit ribosomal RNA.
} 
parsimonious trees (length $=62, \mathrm{CI}=$ $0.984, \mathrm{RI}=0.999, \mathrm{RC}=0.244, \mathrm{HI}=$ 0.616). Both Bayesian and maximum parsimony analyses identified two wellsupported (100\%) clades (Fig. 1). One clade comprised $C$. destructans and 16 isolates from France, and five counties (Mendocino, Napa, Santa Clara, Sonoma, and Stanislaus) in California, all with nearly identical sequences (Fig. 1). The second clade comprised C. macrodidymum and 17 isolates from Chile, and four counties (Mendocino, Napa, Solano, and Sonoma) in California, all with almost identical sequences (Fig. 1). Moreover, a 52-bp insertion in the BT1 beta-tubulin sequence, which was unique and conserved in all $C$. macrodidymum isolates, was not found in C. destructans.

ITS and BT2 datasets were concatenated after there was no significant difference found, based on results of the partition homogeneity test $(P=0.49)$. Sequences of Cylindrocarpon isolates that originated in our study were aligned with published GenBank sequences of three Cylindrocarpon species. Of the 750 nucleotides analyzed, 78 were phylogenetically informative. Maximum parsimony analyses produced three equally parsimonious trees (length $=122, \mathrm{CI}=0.803, \mathrm{RI}=0.883, \mathrm{RC}$ $=0.710, \mathrm{HI}=0.197)$. Both Bayesian and maximum parsimony analyses identified three groups: $C$. destructans, $C$. macrodidymum, and a third group containing the type species of Cylindrocarpon, C. cylindroides (Fig. 2). All three groups were well supported $(100 \%)$. In accordance with the tree based on the ITS and BT1 sequences (Fig. 1), grapevine isolates fell into two different clusters, $C$. destructans and $C$. macrodidymum (Fig. 2). Grapevine isolates in the $C$. destructans clade had nearly identical sequences and formed a remote and well-supported $(100 \%)$ group within

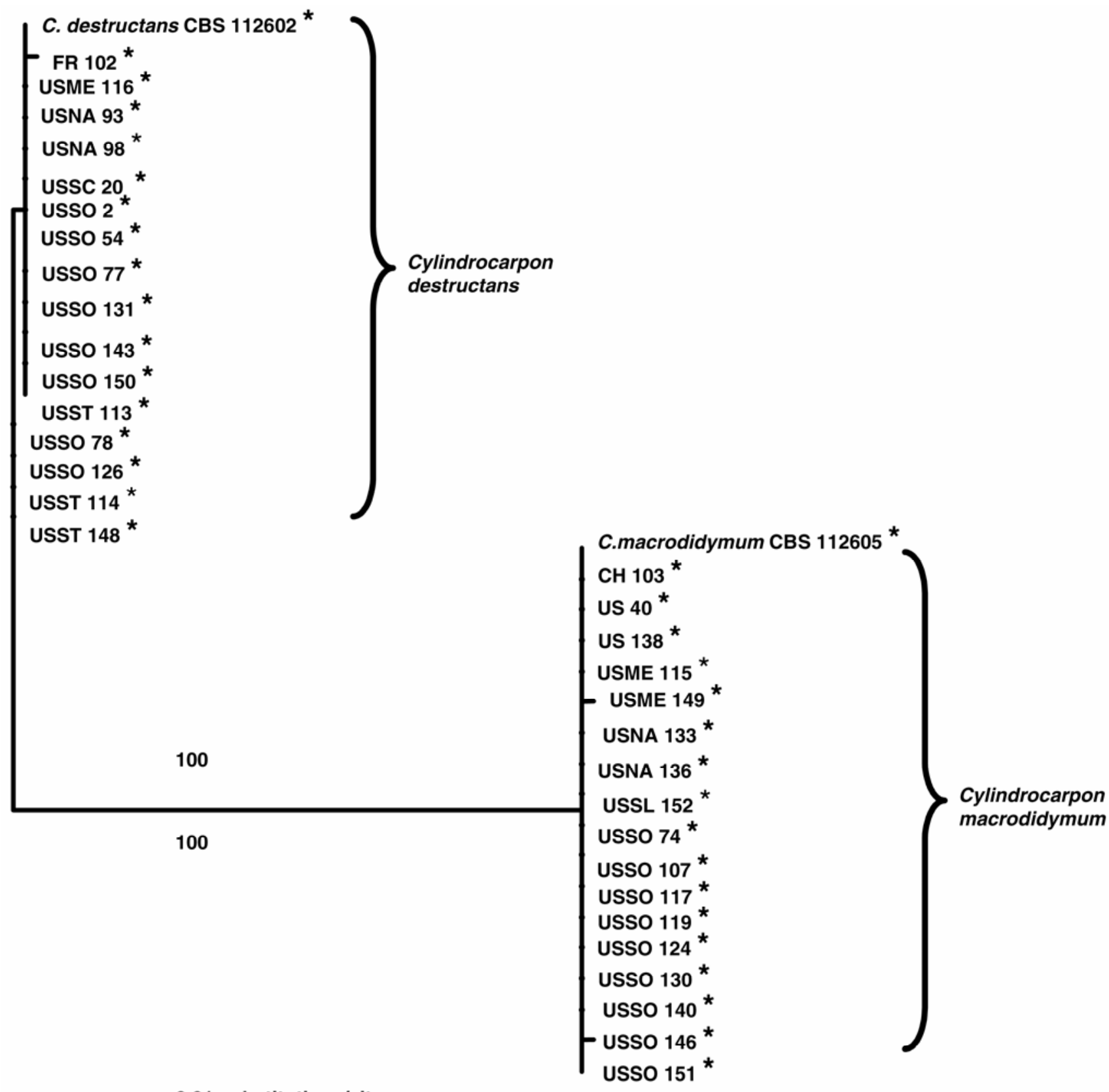

Fig. 1. Bayesian phylogeny obtained using internal transcribed spacer 1, 5.8S ribosomal RNA gene, and internal transcribed spacer 2, and beta-tubulin 1 DNA sequence data. Numbers above branches are probabilities of clades obtained with the Bayesian analyses. Numbers below branches are the bootstrap values obtained with the maximum parsimony analyses. Isolates from grapevines are marked with an asterisk. FR: France, CH: Chile, SA: South Africa, US: United States, USSO: United States Sonoma County, USSL: United States Solano County, USME: United States Mendocino County, USNA: United States Napa County, USST: United States Stanislaus County, USSC: United States Santa Clara. 
the $C$. destructans cluster (Fig. 2). Isolates in the $C$. macrodidymum clade were obtained exclusively from grapevines, and all had nearly identical sequences (Fig. 2).

ITS sequences of the Cylindrocarpon isolates from grapevines were aligned with GenBank sequences from six Cylindrocarpon species, with Nectria cinnabarina (CBS 279.48) as an outgroup. Of the 435 nucleotides analyzed, 40 were parsimony informative. Maximum parsimony analyses yielded 24 equally parsimonious trees (length $=103, \mathrm{CI}=0.873, \mathrm{RI}=0.943, \mathrm{RC}$ $=0.823, \mathrm{HI}=0.127)$. The results of the Bayesian analysis, with probability from maximum parsimony and Bayesian analysis of each clade, are shown in Figure 3. The structure of this tree was consistent with the topology of the tree in Figure 2. Isolates from grapevines grouped into two clusters with the identified isolates of either $C$. destructans or $C$. macrodidymum (Fig. 3). The group of $C$. destructans isolates from grapevines had nearly identical sequences and formed a well-supported (99\%) group sister to $C$. destructans isolated from other hosts (Fig. 3). The sequences of $C$. destructans isolates found on grapevines diverged (2.3 to $3 \%$ ) from the sequences of $C$. destructans isolates found in numerous hosts including Alnus glutinosa, Arbutus menziesii, Malus sp., Panax quinquefolius, and Cornus floridae (Fig. 3). Furthermore, C. macrodidymum isolates, found only on grapevines, had almost indistinguishable sequences and formed a highly supported $(100 \%)$ clade (Fig. 3). The sister clade that included the remaining Cylindrocarpon taxa, comprising C. obtusisporum CBS 183.36 and the type-specimen $C$. cylindroides, was moderately supported at $67 \%$ (Fig. 3).

The mtSSU sequences from our grapevine isolates were aligned with GenBank sequences from 13 species representative of the Neonectria/Cylindrocarpon genus, with Nectria cinnabarina (GJS 91-111) as an outgroup. Of the 657 nucleotides analyzed, 95 were phylogenetically informative. Maximum parsimony analyses resulted in 100 equally parsimonious trees (length $=277, \mathrm{CI}=0.852, \mathrm{RI}=0.914, \mathrm{RC}$ $=0.779, \mathrm{HI}=0.148)$. The results of the Bayesian analysis, with probability from maximum parsimony and Bayesian analysis of each clade, are shown in Figure 4. The tree comprised four well-supported $(100 \%)$ clades within the Neonectria/Cylindrocarpon genus: a clade containing species of the group Neonectria

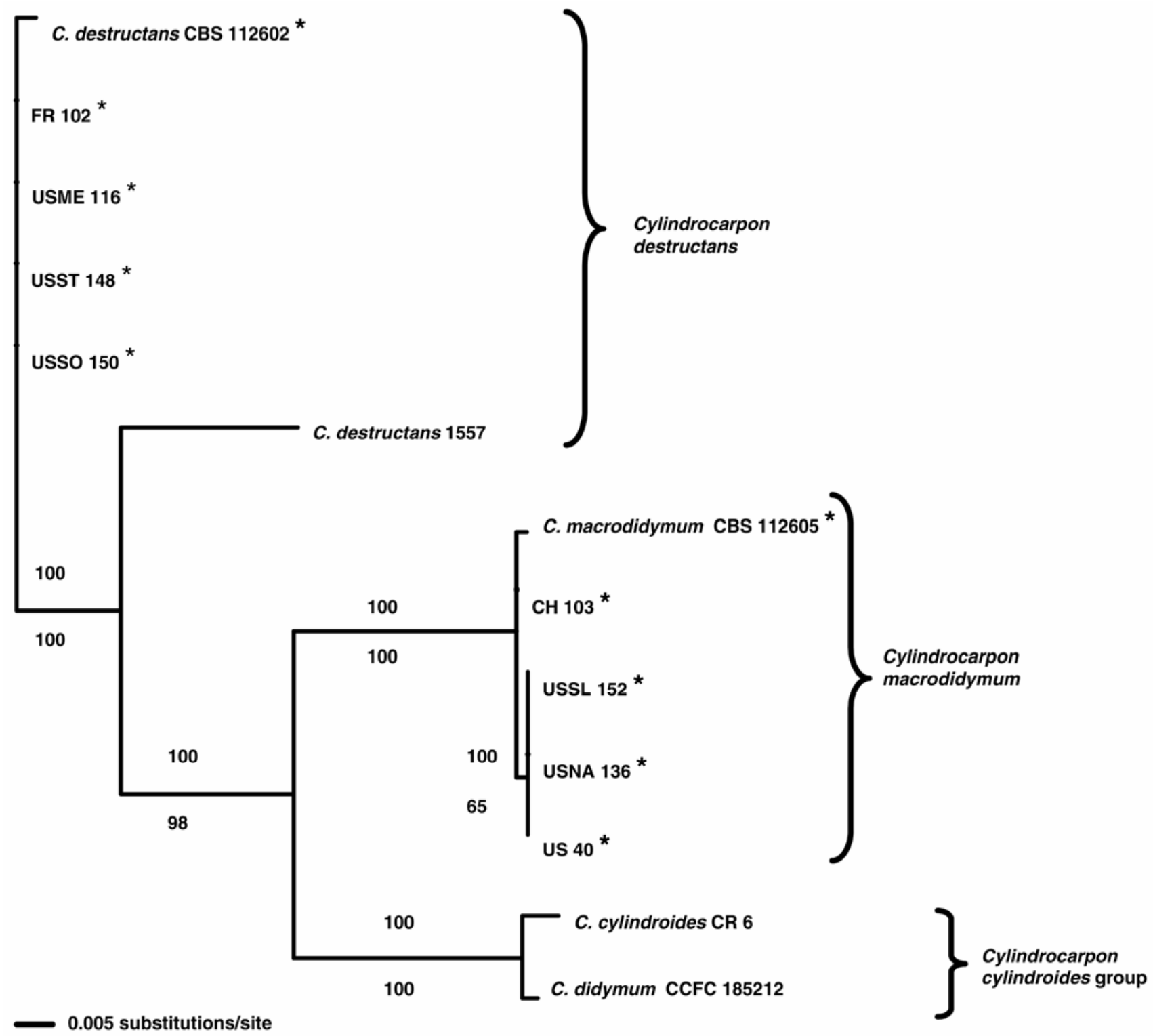

Fig. 2. Bayesian phylogeny obtained using internal transcribed spacer 1, 5.8S ribosomal RNA gene, and internal transcribed spacer 2 , and beta-tubulin 2 DNA sequence data. Numbers above branches are probabilities of clades obtained with the Bayesian analyses. Numbers below branches are the bootstrap values obtained with the maximum parsimony analyses. Isolates from grapevines are marked with an asterisk. FR: France, CH: Chile, SA: South Africa, US: United States, USSO: United States Sonoma County, USSL: United States Solano County, USME: United States Mendocino County, USNA: United States Napa County, USST: United States Stanislaus County. 
mammoidea, the $C$. destructans clade, the $C$. macrodidymum clade, and the clade containing $C$. cylindroides (Fig. 4). Isolates from grapevines were found in two paraphyletic clades, both very well supported (100\%): the C. destructans clade and the C. macrodidymum clade (Fig. 4). The $C$. destructans isolates from grapevines had nearly identical sequences and formed a cluster within the $C$. destructans clade (Fig. 4). The sequences of these $C$. destructans isolates from grapevines diverged (1.51 to $1.7 \%$ ) from the ones of $C$. destructans isolates found in numerous hosts including Prunus persica, Pseudotsuga mensiezii, and Alnus rubra (Fig. 4). All C. macrodidy- mum isolates from grapevines had identical sequences (Fig. 4).

Morphology. Both microconidia and macroconidia, the latter having one to three septa, were produced by all our isolates (Fig. 5). For each type of conidium from each species, the mean and standard deviation of the length and width are given in Table 3. Conidial dimensions (Table 3) were in concordance with the published description of each species $(2,11,21)$. The statistical analysis conducted on populations of isolates grouped according to species allowed us to see that the dimensions of conidia of $C$. macrodidymum $(n=18)$ were significantly $(P<0.001)$ larger than of $C$. destructans $(n=17)$ (Table 3). How- ever, the mean values of spores dimensions were close and their distribution largely overlapped (Table 3). Therefore, a single isolate could not be identified to the species level based on this criterion. In concordance with previous studies (11), $C$. macrodidymum produced fewer chlamydospores than $C$. destructans (data not shown).

All isolates grew at temperatures of 5 , $10,15,20$, and $25^{\circ} \mathrm{C}$, but the optimal temperature was $25^{\circ} \mathrm{C}$. After 6 days at $25^{\circ} \mathrm{C}$, $C$. destructans isolates $(n=17)$ grew significantly $(P<0.001)$ faster (radial growth of $0.34 \pm 0.05 \mathrm{~cm} /$ day) than $C$. macrodidymum isolates $(n=18)$ (radial growth of $0.30 \pm 0.04 \mathrm{~cm} /$ day). Again, given that

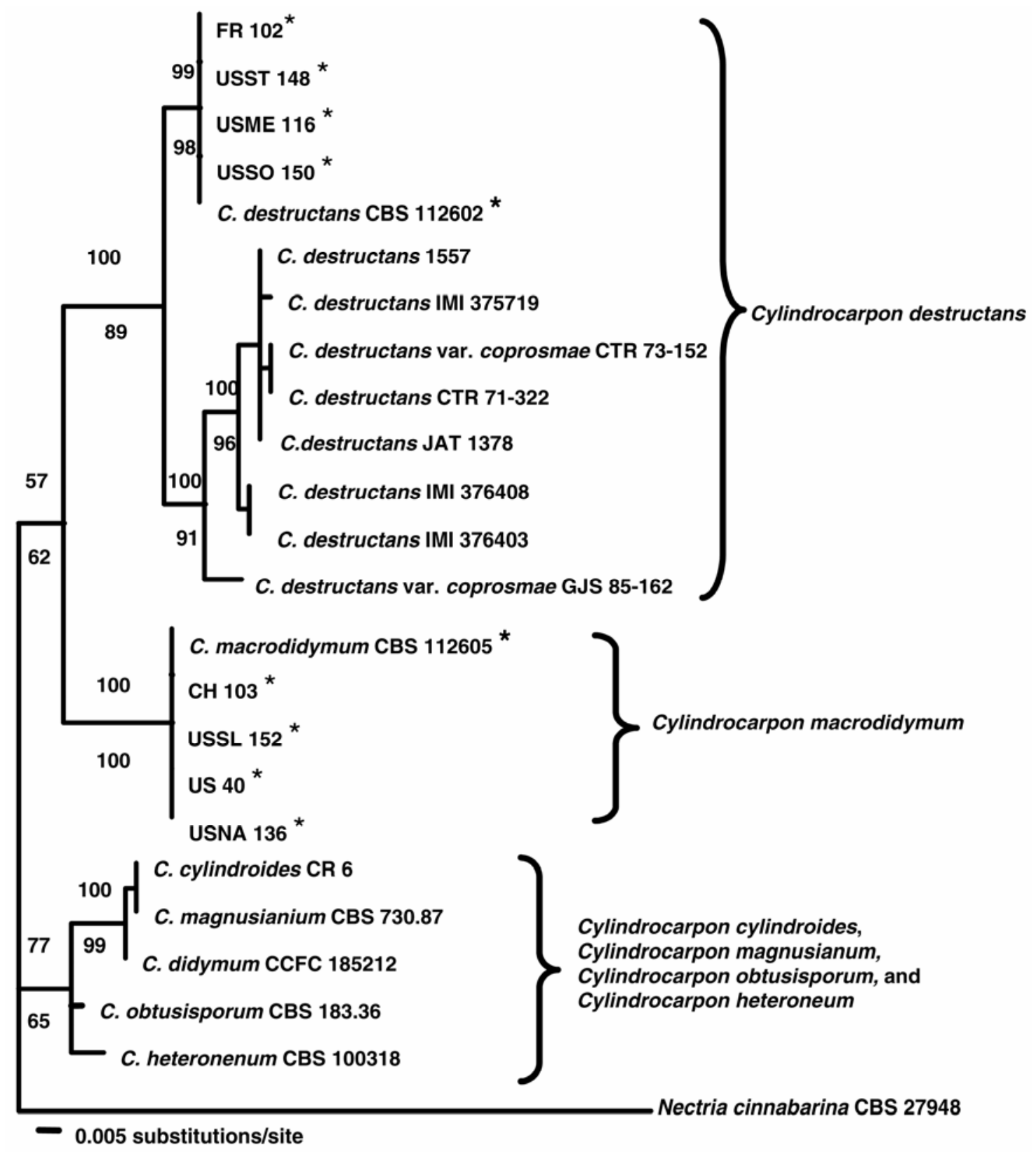

Fig. 3. Bayesian phylogeny obtained using internal transcribed spacer $1,5.8 \mathrm{~S}$ ribosomal RNA gene, and internal transcribed spacer 2. Nectria cinnabarina (CBS 279.48) was used as an outgroup. Numbers above branches are probabilities of clades obtained with the Bayesian analyses. Numbers below branches are the bootstrap values obtained with the maximum parsimony analyses. Isolates from grapevines are marked with an asterisk. FR: France, CH: Chile, SA: South Africa, US: United States, USSO: United States Sonoma County, USSL: United States Solano County, USME: United States Mendocino County, USNA: United States Napa County, USST: United States Stanislaus County. 
these means were very close and the standard deviations overlapped, a single isolate could not be identified to the species level based on this criterion.

Reverse colony colors on PSA after 6 days were variable (data not shown) and could not be used to differentiate groups of isolates. However, reverse colony color on 2\% MEA consistently discriminated $C$. destructans from $C$. macrodidymum: $C$. destructans isolates had a buff reverse, whereas C. macrodidymum isolates had an orange-dark brown reverse (data not shown).

Pathogenicity. A preliminary analysis of the data showed no significant trialtreatment interactions; therefore, the data from the two trials were combined. All Californian C. destructans and C. mac- rodidymum isolates tested were pathogenic to grapevine cv. 5C. All isolates caused significant root rot on grapevine $(P=0.0047)$, and there was no significant level of variation between different isolates or different species (Table 4). Only the $C$. destructans isolate USME 116 produced significant leaf symptoms $(P=$ 0.05) (Table 4). Fungi that matched the morphology of the inoculated isolates were reisolated from inoculated plants (data not shown).

\section{DISCUSSION}

Based on the sequence variation of three independent DNA regions, we identified two species responsible for black foot in California: C. destructans and C. macrodidymum. In agreement with this result, these two species also have each been found to cause black foot of grapevine in other regions of the world (11). This study confirmed the presence, in California grapevines, of $C$. destructans (22) and, for the first time, the occurrence of pathogenic C. macrodidymum.

The present study showed that the $C$. destructans complex, particularly large in the ITS phylogeny, included numerous isolates from various hosts with remarkably variable sequences. The broad variation (4.6 to $5.29 \%$ ) found among isolates identified as the single species $C$. destructans was in concordance with previous findings (25). A more complete sampling of isolates of this $C$. destructans complex from other hosts will be necessary to fully resolve the number of taxa within the $C$.

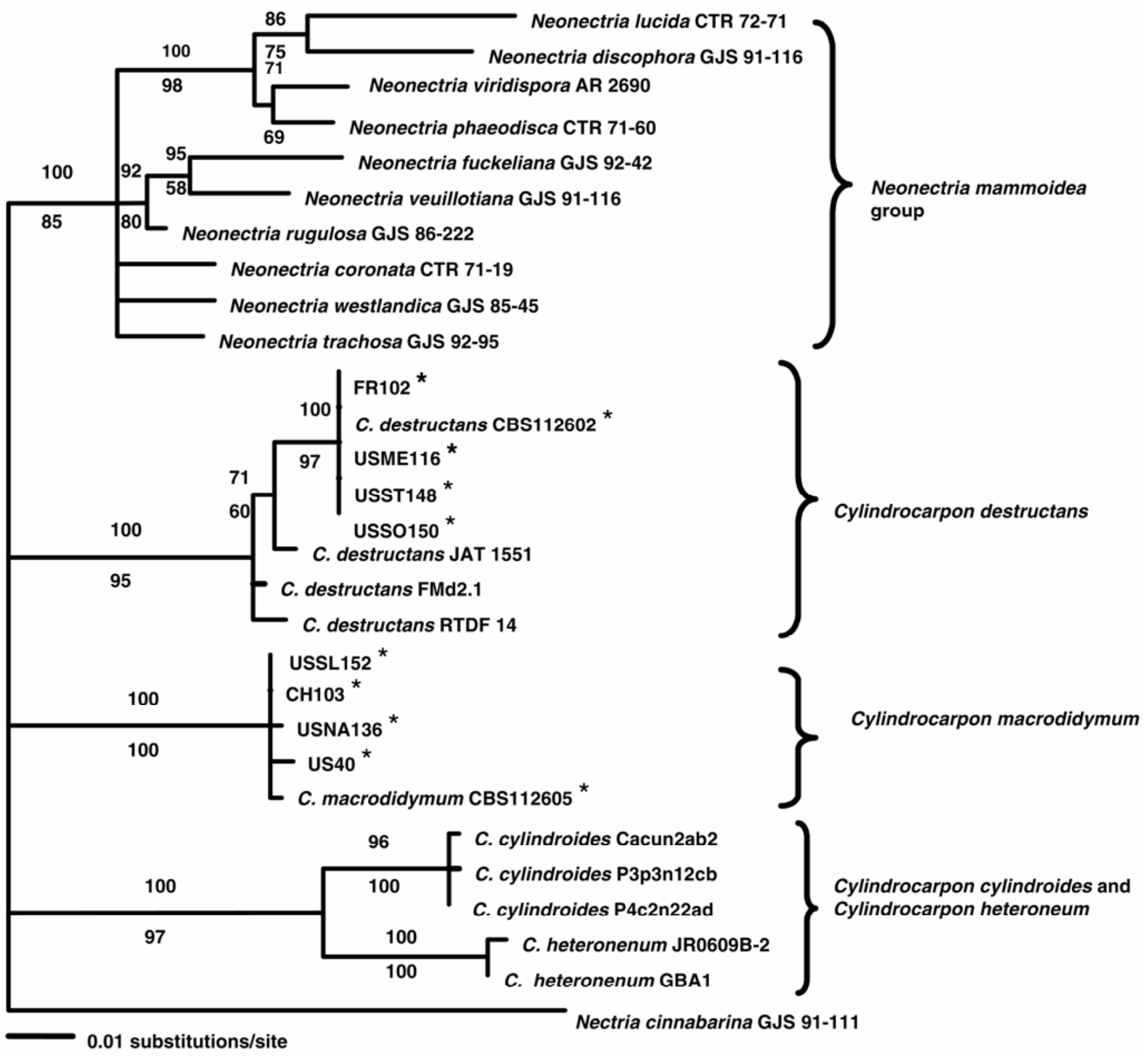

Fig. 4. Bayesian phylogeny obtained using mitochondrial small subunit ribosomal DNA sequence data. Nectria cinnabarina (GJS 91-111) was used as an outgroup. Numbers above branches are probabilities of clades obtained with the Bayesian analyses. Numbers below branches are the bootstrap values obtained with the maximum parsimony analyses. Isolates from grapevines are marked with an asterisk. FR: France, CH: Chile, SA: South Africa, US: United States, USSO: United States Sonoma County, USSL: United States Solano County, USME: United States Mendocino County, USNA: United States Napa County, USST: United States Stanislaus County. 
destructans lineage. Our conclusion that isolates of $C$. destructans from grapevines formed a monophyletic clade within this complex is in agreement with that of Halleen et al. based on partial sequences of ITS, BT, and the nuclear large subunit rDNA (11). Nevertheless, no morphological characteristics allowed us to segregate these grapevine isolates from the rest of $C$. destructans isolates from various hosts as previously described $(2,11,21,24)$. Interestingly, we discovered that these isolates, from extremely diverse geographical origins including France, South Africa, and five counties in California, had nearly no sequence variation.

In this work, the recently described species $C$. macrodidymum, to date known only from grapevine isolates, formed a monophyletic clade in all phylogenies. This conclusion agrees with the work of Halleen et al. (11), who described C. macrodidymum as a new species based on partial sequences of ITS, BT, and the nuclear large subunit rDNA. Our morphological analysis of isolates of $C$. macrodidymum was also in concordance with the description published by Halleen et al.

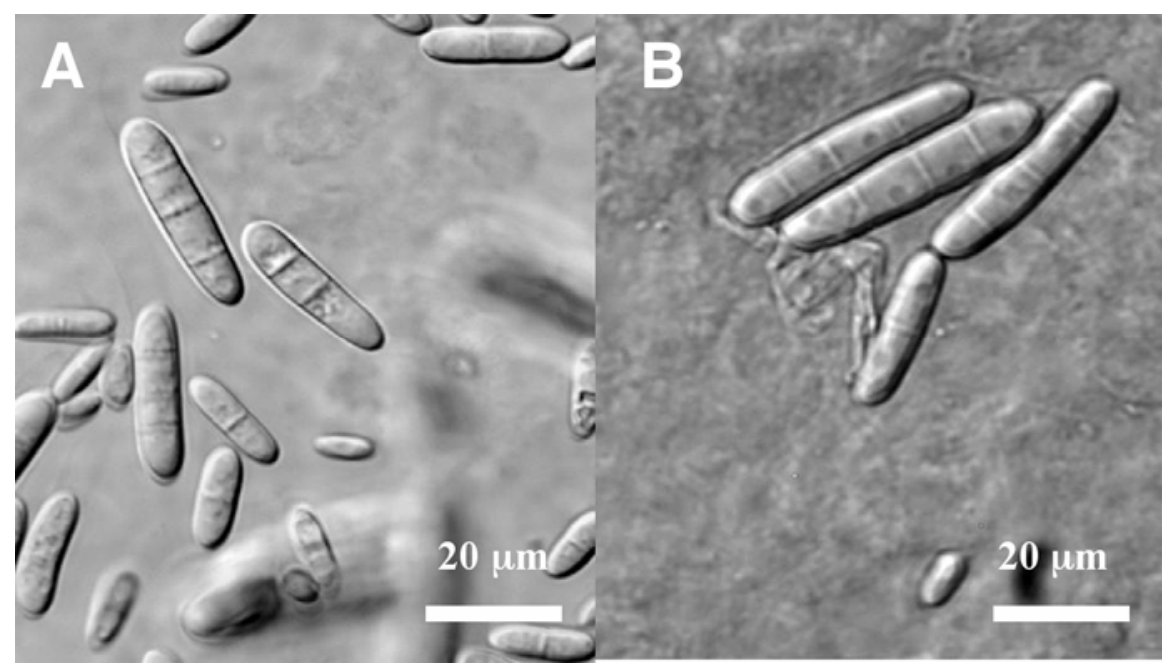

Fig. 5. Conidia of A, Cylindrocarpon destructans, and $\mathbf{B}$, C. macrodidymum. Isolates were grown on Spezieller Nahrstoffarmer agar plus yeast extract, incubated at $25^{\circ} \mathrm{C}$ in a 12 -h light/dark cycle, illuminated by fluorescent strip lights and near-ultraviolet light $(366 \mathrm{~nm})$, and examined after 6 days. Photographs were taken at $\times 400$.

Table 3. Sizes of fungal structures of Cylindrocarpon isolates from grapevines grown on Spezieller Nahrstoffarmer agar plus yeast extract, incubated at $25^{\circ} \mathrm{C}$ in a 12 -h light/dark cycle, illuminated by fluorescent strip lights and near-ultraviolet light $(366 \mathrm{~nm})$, and examined after 6 days

\begin{tabular}{lcccc}
\hline & \multicolumn{4}{c}{ Length $\times$ width $(\boldsymbol{\mu m})^{\mathbf{y}}$} \\
\cline { 2 - 5 } & & \multicolumn{3}{c}{ Macroconidia } \\
\cline { 2 - 5 } Species $^{\mathbf{z}}$ & Microconidia & One-septate & Two-septate & Three-septate \\
\hline C. destructans & $7-12 \times 2.7-4.1$ & $11-18 \times 3-5$ & $18-26 \times 4-5.5$ & $22-31 \times 4.5-6$ \\
C. macrodidymum & $8-16 \times 3.2-5.0$ & $14-27 \times 4-6$ & $26-35 \times 5-7.5$ & $31-41 \times 6-8$ \\
\hline
\end{tabular}

${ }^{y}$ Averages plus or minus standard deviation were derived from 30 observations per isolate for $17 C$. destructans isolates and for 18 C. macrodidymum isolates.

${ }^{z}$ Species was determined from combined internal transcribed spacer, beta-tubulin, and mitochondrial small subunit ribosomal RNA sequence data.

Table 4. Effect of Cylindrocarpon isolates on symptom expression of 6-month-old grapevine rootstock Teleki $5 \mathrm{C}$ after 4 months incubation in a greenhouse

\begin{tabular}{lccc}
\hline Species & Isolate & Leaf $_{\text {symptoms }}^{\mathbf{x}, \mathbf{y}}$ & ${\text { Root } \text { rot }_{\text {index }} \mathbf{x}, \mathbf{z}}^{\text {C. destructans }}$ \\
& USME116 & $1.125 \mathrm{a}$ & $23.2 \mathrm{a}$ \\
& USST148 & $0.250 \mathrm{ab}$ & $14.2 \mathrm{a}$ \\
C. macrodidymum & USST150 & $0.250 \mathrm{ab}$ & $17.0 \mathrm{a}$ \\
& US40 & $0.750 \mathrm{ab}$ & $21.4 \mathrm{a}$ \\
& USNA136 & $0.875 \mathrm{ab}$ & $25.5 \mathrm{a}$ \\
Control & USSOL152 & $0.375 \mathrm{ab}$ & $14.4 \mathrm{a}$ \\
& & $0.000 \mathrm{~b}$ & $00.0 \mathrm{~b}$ \\
\hline
\end{tabular}

${ }^{x}$ Values represent the mean of eight replications for each isolate. Means in a column followed by the same letter are not significantly different according to Tukey's test $(P=0.05)$.

${ }^{y}$ Leaf symptoms were rated using the following scale: $0=$ no symptomatic area on leaves, $1=0$ to $10 \%$ of leaf area necrotic, $2=10$ to $25 \%$ of leaf area necrotic, $3=25$ to $50 \%$ of leaf area necrotic, 4 $=50 \%$ of leaf area necrotic, and $5=100 \%$ of leaf area necrotic.

${ }^{\mathrm{z}}$ Root rot index is the percentage of root with rot.
(11). Surprisingly, we found very little DNA variation in the $C$. macrodidymum clade, contrasting with the wide range of their geographical origin, which includes South Africa, Chile, and four counties in California.

Based solely on published phenotypic characteristics including microconid$\mathrm{ial} /$ macroconidial shape and size, growth rate, production of chlamydospores, and colony pigmentation $(2,11,21,24)$, it was difficult to differentiate $C$. macrodidymum from $C$. destructans. Indeed, between these two species, the mean values of spore sizes were close and their distribution largely overlapped. Although $C$. macrodidymum produced relatively fewer chlamydospores than $C$. destructans, this character was too inconsistent to be used accurately to differentiate these species. Although Halleen et al. (11) distinguished these two species based on their macroconidia, we could not systematically distinguish the slightly bent apical cell of $C$. macrodidymum from the analogous $C$. destructans generally rounded cell. In addition, in the present study, these species could not be distinguished based on their growth rate at optimal temperature of $25^{\circ} \mathrm{C}$ either. Furthermore, in agreement with Halleen et al. (11), pathogenicity tests with various isolates showed that both species induced root rot. There was no relationship between isolates belonging to a specific clade and their degree of aggressiveness. After further investigating the morphology to find particular phenotypic variations paralleling genetic variations, we determined that colony color on $2 \%$ malt extract agar could reliably discriminate isolates from the two species. A 52-bp insertion unique to $C$. macrodidymum also was found to provide a consistent speciesspecific marker.

Contrary to a previously published report in which Cylindrocarpon isolates were identified on the basis of morphological and colony growth characters (23), we did not find evidence of $C$. obtusisporum causing black foot in California. Indeed, none of the ITS sequences of $\mathrm{Cyl}$ indrocarpon isolates from grapevines used in our study clustered with the ITS sequence of C. obtusisporum CBS 183.36 from Solanum tuberosum. Although occurrence of $C$. obtusisporum on grapevines in California cannot be ruled out on the basis of our results, we suspect that $C$. obtusisporum was misidentified.

In conclusion, multigene phylogeny, morphological studies, and pathogenicity tests indicate that both $C$. destructans and C. macrodidymum cause black foot disease in California. This is the first report of $C$. macrodidymum associated with black foot disease in California. Our results indicate that it is possible to differentiate $C$. $d e$ structans from $C$. macrodidymum on the basis of reverse color on $2 \%$ malt extract agar. A 52-bp insertion unique to $C$. $m a c$ rodidymum can also be used to differenti- 
ate this species from other Cylindrocarpon species. This information adds to our currently limited knowledge of Cylindrocarpon on grapevines and may contribute to the development of more effective disease management strategies.

\section{ACKNOWLEDGMENTS}

This research was funded by the California Competitive Grant Program for Research in Viticulture and Enology, the Department of Food \& Agriculture, and the California Grape Rootstock Research Foundation. Special thanks to K. Baumgartner (U.S. Department of AgricultureAgricultural Research Service [USDA-ARS], Davis, CA), R. M. Davis (Department of Plant Pathology, University of California, Davis), G. W. Douhan (Department of Plant Pathology, University of California, Davis), and P. Rolshausen (Department of Plant Pathology, University of California, Davis) for their valuable comments on this manuscript.

\section{LITERATURE CITED}

1. Armengol, J., Vincent, A., Torne, L., GarciaFigueres, F., and Garcia-Jimenez, J. 2001. Fungi associated with esca and grapevine declines in Spain: A three-year survey. Phytopathol. Mediterr. 40:S325-S329.

2. Booth, C. D. 1966. The genus Cylindrocarpon. Mycol. Pap. (CMI) 104:1-56.

3. Brayford, D. 1992. Cylindrocarpon. Pages 103-106 in: Methods for Research on Soilborne Phytopathogenic Fungi. L. L. Singleton, J. D. Mihail, and C. M. Rush, eds. American Phytopathologic Society, St Paul, MN.

4. Brayford, D., Honda, B. M., Mantiri, F. R., and Samuels, G. J. 2004. Neonectria and Cylindrocarpon: The Nectria mammoidea group and species lacking microconidia. Mycologia 96(3):572-597.

5. Felsenstein, J. 1985. Confidence-Limits on Phylogenies - An Approach Using the Bootstrap. Evolution 39(4):783-791.

6. Fourie, P. H., and Halleen, F. 2001. Diagnose van swamsiektes en hul betrokkenheid by terugterswing van jong wingerd. Wynboer 149:19-23.

7. Giovanetti, M., and Mosse, B. 1980. An evaluation of techniques for measuring vesicular-arbuscular infection in roots. New Phytol. 84:489-500.

8. Glass, N. L., and Donaldson, G. C. 1995. Development of primer sets designed for use with the PCR to amplify conserved genes from filamentous ascomycetes. Appl. Environ. Microbiol. 61(4):1323-1330.

9. Grasso, S. 1984. Infezioni di Fusarium oxysporum e di Cylindrocarpon destructans associate a una moria di giovani piante di vite in Sicilia. Inform. Fitopatol. 1:59-63.

10. Grasso, S., and Lio, G. M. 1975. Infezioni de Cylindrocarpon obtusisporum su piante di vite in Sicilian. Vitis 14(1):36-39.

11. Halleen, F., Schroers, H.-J., Groenewald, J. Z., and Crous, P. W. 2004. Novel species of Cylindrocarpon (Neonectria) and Campylocarpon gen. nov. associated with black foot disease of grapevines (Vitis spp.). Stud. Mycol. 50:431455.

12. Ho, W. C., and Ko, W. H. 1997. A simple method for obtaining single-spore isolates of fungi. Bot. Bull. Acad. Sinica 38(1):41-44.

13. Hoagland, D. R., and Arnon, D. I. 1938. The water culture method for growing plant without soil. Calif. AES Bull. 347:36-39.

14. Huelsenbeck, J. P., and Ronquist, F. 2001. MRBAYES: Bayesian inference of phylogenetic trees. Bioinformatics 17(8):754-755.

15. Li, K. N., Rouse, D. J., and German, T. L. 1994. PCR primers that allows intergenic differentiation of ascomycetes and their application in Verticillium spp. Appl. Environ. Microbiol. 60:4324-4331.

16. Maddison, W. P., and Maddison, D. R. 1992. MacClade. Analysis of phylogeny and character evolution, Version 3. Sinauer Associates, Sunderland, MA.

17. Maluta, D. R., and Larignon, P. 1991. Pied-noir: Mieux vaut prevenir. Viticulture 11:71-72.

18. Mantiri, F. R., Samuels, G. J., Rahe, J. E., and Honda, B. M. 2001. Phylogenetic relationships in Neonectria species having Cylindrocarpon anamorphs inferred from mitochondrial ribosomal DNA sequences. Can. J. Bot. 79(3):334340.

19. Posada, D., and Crandall, K. A. 1998. MODELTEST: Testing the model of DNA substitution. Bioinformatics 14(9):817-818.
20. Rego, M. C., Oliveira, H., Carvalho, A., and Phillips, A. 2000. Involvement of Phaeoacremonium spp. and Cylindrocarpon destructans with grapevine decline in Portugal. Phytopathol. Mediterr. 39:76-79.

21. Samuels, G. J., and Brayford, D. 1990. Variation in Nectria radicicola and its Anamorph, Cylindrocarpon destructans. Mycol. Res. 94:433-442.

22. Scheck, H. J., Vasquez, S. J., and Gubler, W. D. 1998. Grape growers report losses to black foot and grapevine decline. Calif. Agric. 52:19-23.

23. Scheck, H. J., Vasquez, S. J., Gubler, W. D., and Fogle, D. 1998. First report of black-foot disease, caused by Cylindrocarpon obtusisporum, of grapevine in California. Plant Dis. $82: 448$

24. Seifert, K. A., and Axelrood, P. E. 1998. Fungi Canadenses No. 337: Cylindrocarpon destructans var. destructans. Can. J. Plant Pathol. 20(1):115-117.

25. Seifert, K. A., McMullen, C. R., Yee, D., Reeleder, R. D., and Dobinson, K. F. 2003. Molecular differentiation and detection of ginseng-adapted isolates of the root rot fungus Cylindrocarpon destructans. Phytopathology 93:1533-1542.

26. Sweetingham, M. 1983. Studies on the nature and pathogenicity of soilborne Cylindrocarpon spp. Ph.D. thesis. University of Tasmania, Hobart, Tasmania, Australia.

27. Taylor, J. W., Jacobson, D. J., Kroken, S. Kasuga, T., Geiser, D. M., Hibbett, D. S., and Fisher, M. C. 2000. Phylogenetic species recognition and species concepts in fungi. Fungal Genet. Biol. 31:21-32.

28. Thompson, J. D., Gibson, T. J., Plewniak, F., Jeanmougin, F., and Higgins, D. G. 1997. The ClustalX windows interface: Flexible strategies for multiple sequence alignment aided by quality analysis tools. Nucleic Acids Res. 25:4876-4882.

29. White, T. J., Bruns, T., Lee, S., and Taylor, J. W. 1990. Amplification and direct sequencing of fungal ribosomal RNA genes for phylogenetics. Pages 315-322 in: PCR Protocols: A Guide to Methods and Applications. M. A. Innis, D. H. Gelfand, J. J. Sninsky, and T. J. White, eds. Academic Press, San Diego, CA. 